\title{
A Confederação dos Tamoios como escrita da história nacional e da escravidão*
}

\author{
The Poem Confederação dos Tamoios as Writing of National History \\ and Slavery
}

Danilo José Zioni Ferretti

danilozf@ufsj.edu.br

Professor Adjunto

Universidade Federal de São João del Rei

Rua Santa Teresa, 106 - Centro

36300-114 - São João del Rei - MG

Brasil

\begin{abstract}
Resumo
Este artigo é uma tentativa inicial de reavaliação da obra $A$ Confederação dos Tamoios (1856), do poeta romântico Gonçalves de Magalhães, tomando-a como um exercício de escrita da história brasileira e do papel nela desempenhado pela escravidão. Para tanto, busca-se compreender as inovações oitocentistas do épico mediante uma discussão sobre o diálogo entre literatura e conhecimento histórico no Brasil oitocentista. Aponta-se que ambos compartilharam o objetivo de servir como meios de orientação da coletividade nacional, empenhando-se em conferir significação e direção à sua própria experiência do tempo. Analisa-se a interpretação da história contida no poema e a centralidade conferida à questão da escravidão, indicando que o indianismo de Magalhães era também um antiescravismo.
\end{abstract}

\section{Palavras-chave}

Poesia; Romantismo; Escravidão.

\begin{abstract}
This article is an initial attempt to reassess the work $A$ Confederação dos Tamoios (The Tamoios Confederation, 1856), a literary piece by Gonçalves de Magalhães, a Brazilian romantic Poet, portraying it as a written exercise of the Brazilian history and of the role slavery played in it. To attain this aim, it seeks to understand the epic nineteenth-century innovations by discussing the dialogue between literature and historical knowledge in Brazil. It points out that both shared the goal of serving as a means of providing guidance to the national collectivity, in an effort to produce a meaning and a direction to its own experience in time. The analysis is focused on the interpretation of history contained in the poem and on the central place ascribed to the issue of slavery, indicating that Magalhães' Indianism was also an anti-slavery standpoint.
\end{abstract}

\section{Keywords}

Poetry; Romanticism; Slavery.

Recebido em: 4/8/2014

Aprovado em: 6/11/2014

\footnotetext{
* Pesquisa financiada pela Fundação de Amparo à Pesquisa do Estado de Minas Gerais (FAPEMIG). Agradeço a Marcos Machado Nunes o apoio e a interlocução intelectual que permitiram afinar alguns pontos apresentados neste artigo.
} 
Desqualificada por José de Alencar devido a motivos formais, falta de imaginação e vigor estético na descrição da natureza e de seus personagens, $A$ Confederação dos Tamoios, poema épico de Gonçalves de Magalhães, tampouco entusiasmou seus analistas posteriores. Já é tempo de retirá-lo do limbo centenário ao qual foi relegado (CAMPATO JR. 2008). Não porque se busque aqui defender alguma potencialidade estética, mas porque esse poema foi um exercício de escrita da nação e sua história, de importância fundamental para compreender o projeto intelectual romântico brasileiro. Tomarei como objeto a escrita da história nacional e da escravidão pelo poema épico de Magalhães. Tomá-lo como um exercício de escrita

consiste em propor contextualizações que permitam localizar os escritos analisados no seio do conjunto de ações que lhes dão sentido. É sob essa condição que esses escritos podem se tornar testemunhos preciosos da experiência de indivíduos do passado, captada mediante a manipulação que deles faziam para agir no mundo. A 'literatura', como realidade histórica e social, fazia parte dessa experiência [...]. Nós a consideramos necessariamente em nossa análise, mas conquanto ela fosse mobilizada, entre os múltiplos gestos sociais que então implicavam o uso dos escritos (JOUHAUD; RIBARD; SCHAPIRA 2009, p. 17, 18). ${ }^{1}$

\section{Diálogos entre a poesia épica e o conhecimento histórico no Brasil do século XIX}

Tomando como referência as obras de Homero, Aristóteles apresentava, em sua Poética, uma definição da epopeia de onde se destacava, dentre outros elementos, a sua caracterização como um meio de imitação em verso, em estilo elevado, das ações (normalmente guerreiras) de um herói. Este devia ser de bom caráter, devendo a epopeia pintar o homem melhor do que ele é. Pautava-se, assim, pelo verossímil, permitindo, contudo, incluir intervenções sobrenaturais, identificadas com o maravilhoso. Sua estrutura deveria ser caracterizada por certa unidade de ação, dividida em princípio, meio e fim, em que se permitia o desdobramento de peripécias e acontecimentos patéticos (RAMALHO 2004, p. 111-172). No entanto, ainda que possamos partir dessa definição canônica, nada seria mais enganador que nos restringirmos a ela, uma vez que ao longo do tempo a caracterização da epopeia foi fruto de intenso debate cuja reconstituição escapa aos objetivos do presente texto.

Durante a Idade Moderna, houve um esforço de codificação das regras do gênero a partir do confronto dos modelos da antiguidade clássica com os exercícios de escrita épica posterior (HANSEN 2008). Desde o Romantismo, porém, essa tendência normativa tendeu a ser afrouxada, indicando uma crescente polissemia na definição da poesia épica que atinge situação paroxística na atualidade, momento em que as fronteiras conceituais ameaçam perder sua

\footnotetext{
1 No original: "Notre demarche consiste alors à proposer des contextualisations permettant de deplacer les écrits que nous analysons au sein de l'ensemble des actions qui leur donnaient sens. C'est à cette condition que ces écrits peuvent devenir un témoignage précieux sur l'espérience d'individus du passé, saisie à travers la manipulation qu'ils en faisaient pour agir dans le monde. La 'littérature', comme réalité historique et sociale, faisait partie de cette expérience [...]. Nous la prenons donc nécessairement en compte dans notre analyse, mais en tant qu'elle était mobilisée, parmi les multiples gestes sociaux qui impliquaient alors d'user de l'ecrit[...]".
} 
coesão mínima, seja pela extensão geográfica de casos estudados, que vão muito além da Europa Ocidental, seja pelo seu aprofundamento temporal, que inclui manifestações em períodos antes pouco considerados como a Idade Média e a contemporaneidade (GOYET 2009).

Se alguns autores, como Florence Goyet (2009), se esforçam por reconstituir uma definição da epopeia, pensar a escrita épica de Gonçalves de Magalhães, escritor brasileiro do século XIX, nos remete a outro caminho, a saber, pensar a especificidade do uso feito do épico na periferia do Ocidente e na contemporaneidade, ou seja, em espaço e tempo diferentes daqueles que deram base às definições canônicas. Principalmente a questão do épico na contemporaneidade nos interessa na medida em que o início do século XIX foi marcado pela consolidação de uma corrente que afirmava a morte da epopeia. Remontando a Vico mas encontrando em Hegel seu expoente, essa corrente baseava-se em certo evolucionismo linear, tendo como pressuposto que a cada época histórica correspondessem formas literárias específicas (CHAUVIN 2008). Para Vico, a epopeia era a forma correspondente à sociedade bárbara da terceira fase da era heroica; já para Hegel, dentre outros elementos, seu apelo à honra e heroicidade não corresponderiam ao prosaísmo da época contemporânea, caracterizando-se aí como uma forma anacrônica (NEIVA 2014).

No entanto, a direção de várias pesquisas atuais tende a questionar essa tese da incompatibilidade intrínseca entre poesia épica e contemporaneidade, mostrando a versatilidade do gênero que, ao invés de ter-se esgotado, passou por várias transformações a partir de meados do século XVIII (NEIVA 2008; GOYET 2009). Muito mais reveladora que a identificação do épico como algo anacrônico parece ser a constatação de que a relação dos autores do século XIX com o gênero variou entre "nostalgia, recusa veemente e tentativa de recriação" (GOYET 2009). Vale explorar a última via visando a uma melhor compreensão da epopeia de Magalhães.

A historiografia recente sobre as diversas formas do gênero torna cada vez mais evidente a continuidade da produção de poesia épica ao longo dos séculos XIX e XX, não somente no Brasil, mas um pouco por todo o ocidente (NEIVA 2008). O caso francês, ao qual Magalhães e os românticos brasileiros estavam mais diretamente ligados, é esclarecedor nesse sentido. O investimento em uma poesia épica renovada se desdobrou em pelo menos três vertentes: uma que aproximava o épico do drama, outra que tornava íntima a gesta heroica na forma da "epopeia do Homem interior" e, por fim, a epopeia "Humanitária" (em Lamartine), ou "filosófica" (em Quinet), caracterizadas pelo diálogo entre o poema épico e a história filosófica (MILLET 2008, p. 12). No presente texto, a vertente que mais nos interessa é a terceira. Ela nos leva a questionar as relações da poesia épica menos com outros gêneros literários e mais com esse outro saber que é a história.

Percebe-se, no Brasil do século XIX, um diálogo entre a literatura e o saber histórico, discursos cujas fronteiras estavam em fase de (re)definição. Mais precisamente, as definições de uma literatura nacional e de uma história 
nacional brasileira constituíram-se como projetos concebidos e desenvolvidos basicamente a partir do mesmo momento, por volta da década de 1830 . Nota-se, então, um esforço coletivo e articulado de intelectuais brasileiros no sentido da elaboração sistemática de discursos de identificação nacional e de certa institucionalização que lhe dê suporte. Essa última se manifesta, a partir de 1836, nas iniciativas editoriais (revista Nitheroy, Jornal dos Debates Políticos e Literários) que ajudam a estruturar um grupo de literatos românticos, assim como na criação, em 1838, do Instituto Histórico e Geográfico Brasileiro (IHGB), espaço por excelência de criação de uma história nacional (ROZEAUX 2012; GUIMARÃES 1988). Os agentes envolvidos em cada um dos projetos buscaram garantir suas especificidades, mas possuíram inúmeros pontos de contato e estabeleceram um diálogo constante, participando, por vezes, de ambos, como foi o caso de Gonçalves de Magalhaes (ARAUJO 2008. p. 119-130). Para melhor compreendermos o processo, vale evitar projetar no passado as fronteiras atuais entre as disciplinas e assim romper o esforço dialógico de escrita da literatura e da história nacional no século XIX, em alguns momentos elaborado pelos mesmos agentes (LYON-CAEN; RIBARD 2010, p. 6). Afinal, Januário da Cunha Barbosa, Gonçalves de Magalhães, Gonçalves Dias, Francisco Adolfo de Varnhagen, dentre outros, foram intelectuais que dividiram suas atividades entre a produção de textos literários e de trabalhos de erudição histórica, ainda que com ênfases e articulações diferenciadas para cada um deles (SILVEIRA 2009).

O principal desdobramento desse diálogo entre a literatura e o saber histórico parece ter sido o próprio surgimento do moderno conceito de história, linear e progressivo, tanto na Europa quanto no Brasil. Para o caso europeu, Reinhart Koselleck indicou como os dois campos, a partir de meados do século XVIII, levaram a cabo uma fusão na qual a História "se submetia ao preceito poetológico de criar unidades fundadoras de sentido. Exigia-se dela mais arte expositiva; ao invés de narrar séries cronológicas, ela deveria averiguar os motivos ocultos e extrair uma ordem interior dos acontecimentos contingentes" (KOSELLECK 2004, p. 53). ${ }^{2}$ Nesse processo, foi comum o uso da metáfora literária para definir uma nova forma de História que não mais fosse o relato desconexo de histórias particulares e se transformasse no coletivo singular, dotado de unidade interna, conferida pelo direcionamento progressivo de todo o processo a um fim comum, um telos, constituindo assim o que se caracterizou como sendo as histórias filosóficas.

O Brasil, por sua vez, desenvolveu suas próprias elaborações do moderno conceito de História a partir das primeiras décadas do século XIX, em um processo complexo no qual o poeta filósofo Gonçalves de Magalhães teve papel de destaque, podendo ser considerado um dos pioneiros de uma visão moderna do tempo (ARAUJO 2008). Baseando-se na metáfora literária, Magalhães defendia, em 1836, que "a história, como todo drama, supõe lugar de cena, atores, paixões, um fato progressivo, que se desenvolve, que tem sua razão,

\footnotetext{
${ }^{2}$ No original: "[...] se sometía al precepto poetológico de crear unidades fundadoras de sentido. Se reclamaba de ella más arte expositivo; en lugar de narrar series cronológicas, debía averiguar los motivos ocultos y extraer un orden interior de los sucesos contingentes".
} 
que tem uma causa, e um fim. Sem essas condições nem há história, nem drama" (MAGALHÃES 1836b, p. 142). Assim, a literatura fornecia à história o modelo para sua redefinição como processo linear progressivo, como uma história filosófica.

Esse processo de diálogo parece ter sido marcado, também no Brasil, pela atenuação, mas não supressão, da diferença básica entre a natureza epistemológica do discurso épico e do discurso histórico. O primeiro, pelas regras clássicas do gênero, seria baseado não na representação referencial de coisas de fato, mas em operação intelectual compositiva a partir da imitação verossímil de opiniões e modelos de textos poéticos ou históricos anteriores (HANSEN 2008, p. 20). O segundo buscaria refletir a realidade factual de forma fiel, elaborando um discurso cujo caráter de verdade estaria calcado, cada vez mais, na apresentação de vasto aparato de provas documentais, conforme os princípios da tradição erudita, retomados, a seu modo, pelo historicismo oitocentista (ESCUDIER 2003). Diante dessa polaridade básica, Magalhães parece ter realizado um movimento de relativa quebra da fixidez das regras da poesia épica, moldando-as a uma maior aproximação com um discurso fiel ao referente.

Essa orientação é explicitada em carta, de 1856, a Araújo Porto Alegre. Refutando as críticas em que Alencar o acusava de não ter dado espaço para o desenvolvimento dos mitos indígenas, Magalhães indicava uma compreensão reformada da poesia:

Dize-lhe [ao autor das cartas] [...] que das crenças e tradições dos índios do Brasil eu disse o que se sabe, e de propósito não quis inventar novos mitos e novas tradições, que seriam sem valor algum, faltando-lhes o testemunho da história; além de que não está muito nisso a poesia moderna. Morta estaria a poesia se só vivesse de mitos, de ficções, de personificações de ideias, de endeusamento de raça e de mentiras (MAGALHÃES 1856).

Magalhães defendia-se propondo uma poesia que atenuasse as referências ao mito e mesmo a seu caráter fictício; no limite, uma poesia mais fiel à história. Conforme veremos, ele o faria, no entanto, considerando a mediação de um "modelo interior", elaborado pela subjetividade do artista que captaria a manifestação da divindade através da observação da natureza e a interpretaria na forma de arte.

Se, anteriormente, tínhamos visto como a história havia se transformado pela aproximação à poesia, agora percebemos que o movimento contrário, de aproximação da poesia à história, também ocorreu - aliás, semelhante ao que Koselleck indicara para o caso alemão. A poesia de Magalhães aproximava-se da referencialidade do discurso histórico, voluntariamente limitando, sem anular, a imaginação e a invenção mítica. O interessante e original, em relação ao caso alemão, é que Magalhães o fazia ainda dentro do gênero épico, e não deslizando para a nova linguagem do romance realista, conforme apresentado por Koselleck. Eloquente indício desse processo seria o aparato de notas eruditas que, no final da obra, desenvolviam informações sobre costumes indígenas e 
indicavam as fontes documentais que serviram de base à elaboração poética, em clara continuidade da tendência já presente nos autores luso-brasileiros setecentistas (HANSEN 2008, p. 85). Magalhães poetizava a história ao unificá-la e "historizava" a poesia épica, tornando-a mais estritamente realista.

Essa proximidade entre epopeia e história, aliás, parece ser um ponto importante que talvez nos ajude a compreender o entusiasmo com o gênero épico no Brasil oitocentista. Esse apego ao épico não era somente motivado pelo prestígio que possuía como ápice da hierarquia dos gêneros. A epopeia respondia, com sua busca clássica de ensinar deleitando, aos anseios do nascente nacionalismo por despertar entusiasmo coletivo e possibilitar a visibilização e a atribuição de sentido a essa realidade até então pouco palpável que eram as novas nações e a sua temporalidade própria. $E$, para tanto, parece ter desempenhado um papel fundamental a possibilidade de orientação coletiva mediante uma interpretação do sentido geral de um passado que assumiria, dessa forma, um caráter unificado.

Gonçalves de Magalhães, especialmente, destacava-se como intelectual empenhado em conferir centralidade à leitura do passado e da história. Em 1836, de Paris, afirmava que "Jamais uma nação poderá prever o seu futuro, quando ela não conhece o que ela é, comparativamente com o que foi. Estudar o passado é ver melhor o presente, é saber como se deve marchar" (MAGALHÃES 1836b, p. 145). Essa busca de orientação pelo estudo do passado tornar-se-ia mais premente à medida que, de volta ao Brasil, tinha contato direto com a situação de conflito social generalizado que marcou o período regencial. Ela se tornava fundamental para decidir da "sorte dos Impérios", conforme afirmava em 1837:

Se há um estudo próprio a todas as capacidades, e no qual todas as inteligências podem colher úteis e importantes lições, sobre a ordem providencial das coisas humanas, é sem dúvida alguma o estudo da História. [...] É sempre o bem, que a humanidade procura; e nesta pesquisa tão pleiteada sobre a terra, ela realiza as vistas da Providência. Seria um grave absurdo acreditar-se que uma estúpida fatalidade, ou meras combinações dos homens, decidem da sorte dos Impérios. A não considerar a História, se não por este lado filosófico, já deveria ela merecer toda a importância científica de uma meditação, que, exaltando o nosso espírito, nos põe em estado de julgar da nossa missão terrestre. Mas ao lado desta parte especulativa, quantas lições práticas não podemos tirar? Quantas aplicações não podemos fazer? A imagem do passado, assim presente a nossos olhos, nos mostra os tropeços da estrada, e nos ensina a evitar duvidosas e arriscadas experiências (Jornal dos Debates Políticos e Literários, 23 maio 1837).

A História, para Magalhães, ainda que progressiva e linear, era guiada, acima de tudo, por uma vontade divina, por uma "ordem providencial". Ela aparecia dotada de um sentido teleológico transcendente, salvacionista, mas cuja compreensão poderia e deveria ser apreendida pelos homens, para que bem julgassem sua "missão terrestre". E isso poderia ser feito por meio do saber histórico. Este seria dotado de utilidade por auxiliar a indicar caminhos de se atingir o bem, ressaltando a sua centralidade para a elaboração de projeções de futuro. 
Essa capacidade de orientação da coletividade reforçava a convergência entre o saber histórico e a poesia, na medida em que, para Magalhães, mais que qualquer outra forma de expressão, esta última teria o poder de "sublimes lições aos homens dita[r]", sendo a linguagem adequada para sondar a sorte dos Impérios, conforme indica o poema "A poesia", de 1836 (MAGALHÃES 1836a, p. 35). Nele o autor recusa a visão de que a poesia seria "só de ficções amiga", afinal "tu não és um fantasma de beleza./ Falaz sonho de mente delirante,/ E da mentira a deusa" (MAGALHÃES 1836a, p. 33). Ao contrário, a poesia aparece como fonte superior de acesso à verdade.

Baseando-se em certa concepção de mimese de fundo platônico, comum ao romantismo francês e absorvida mediante a teorização estético-filosófica de Victor Cousin, para Magalhães a poesia seria, "a imagem do Eterno" (MAGALHÃES $1836 a$, p. 38) que se projetaria no interior do poeta, que, por sua vez, teria como missão expressá-la ao mundo (ABRAMS 2010, p. 66-70; BRIX 2001). Conforme teorizaria, em 1876, a poesia permitia "conceber a perfeição ideal em todas as coisas, morais e físicas" (MAGALHÃES 1876, p. 283). Magalhães conferia uma dimensão epistêmica superior à linguagem poética, por sua capacidade de captar o aspecto transcendente da realidade, seu caráter divino, que, conforme vimos, tinha um papel central na sua concepção da história. Ele assim compartilhava a visão do romantismo francês de que "ultrapassando todas as outras atividades humanas na representação da beleza universal, a poesia [era] chamada a suplantar a filosofia, a história, as ciências, as artes e a permanecer - segundo os termos de Hegel - a única instrutora do espírito, religião suprema e última do gênero humano", a "ferramenta essencial de deciframento do mundo" (BRIX 2001, p. 55-56). Ela era o meio por excelência para sondar a sorte transcendente dos impérios e das nações.

Conforme indicou François Hartog, o século XIX é o momento em que "história e literatura tornam-se um casal moderno, dando seu assentimento ao tempo moderno, [...] e nesse tempo novo, eles encontrarão uma fonte e uma chave de inteligibilidade do mundo" (HARTOG 2013). A poesia épica, em diálogo com a história, foi a linguagem privilegiada por Magalhaes para decifrar o tempo, tornando-se meio poderoso de orientação da coletividade. E, de fato, a Confederação dos Tamoios foi concebida em um momento de intenso embate político-social em torno da escravidão, quando os referenciais temporais que definiam os nexos dessa instituição com a nação passavam por uma redefinição, conforme passamos a tratar.

\section{Uma escrita forjada entre o indianismo emergente e o antiescravismo liberal-moderado}

Entre a concepção, escrita e publicação de A Confederação dos Tamoios, passaram-se mais de duas décadas. Nesse período, Magalhães vivenciou os embates, por vezes violentos, entre projetos de configuração do Estado nacional, desencadeados durante o período regencial, e a estabilização do regime monárquico, que coincidiu com o momento de publicação da obra em 1856. Podemos recuar a primeira notícia de sua elaboração não ao ano de 1837 , 
conforme vem afirmando a bibliografia especializada, mas a 1834, quando o cônego Januário da Cunha Barbosa, então redator do Correio Oficial, órgão oficial do governo regencial, publicava uma carta enviada de Paris por Gonçalves de Magalhães, que informava sobre a escrita de um poema épico e trazia um trecho de seu primeiro canto. Escrevia o jovem poeta:

Assim, no momento de repousar dos meus estudos, solto as velas à
minha imaginação, e vejo que dos poemas, que possuímos, nenhum se
ocupa particularmente das nossas tribos, a não ser o Caramuru, onde os
índios são algum tanto maltratados; quanto às nossas composições mais
curtas são todas calculadas pelo modelo de Horácio, Camões, Boccage,
etc., e de quantos poetaram à maneira dos gregos e dos romanos;
nada de poesia nacional, nada de poesia própria, natural e brasileira.
Os modernos sacodiram o jugo da grega mitologia, bela para os gregos
e romanos, exótica para nós; Byron, Cowper, De Lamartine, Delavigne,
Mickiewiez têm dado exemplos de uma nova maneira de poetar. A nossa
poesia deve participar mais do caráter oriental, isto se observa na nossa
música voluptuosa, e lânguida, das nossas modinhas, e da nossa maneira
de falar; o Sol dos Trópicos e os aspectos do país concorrem para isso. Por
que, pois, não faremos uma poesia brasileira? Para não ficar em reflexões
inúteis ousei empreender um Romance; estendi-o depois, e fiquei em fazer
um Poema. Escolhi a confederação dos Tamoios contra os Portugueses:
para isso li na biblioteca real a vida do Padre Anchieta, e do Padre
Nóbrega, por Vasconcelos; Lamartinière no artigo - Brasil; Beaucham
e Ferdinand Denis, quase que me foram inúteis. Tenho o primeiro canto
feito, e começo o segundo. Devo dizer que adotei, quanto ao estilo de
português, o de Felinto Elísio colocado sempre que a brandura do objeto
não me pedia fluidez; a mitologia de nada me servira. O cristianismo e
os costumes dos selvagens me deram imagens, e a Natureza me dará
comparações; se no fim da minha obra não prestar, pouco se perderá
(Correio Oficial, 30 ago. 1834).

Muitas considerações podem ser feitas a partir do trecho, aparentemente desconhecido dos estudos atuais, mas aqui nos interessa destacar que Magalhães explicitava, provavelmente pela primeira vez por um brasileiro, um projeto de poesia nacional calcado no indianismo, entendido, de forma restrita, como o movimento literário centrado na valorização da figura do indígena. Ele antecedia, em três anos, a Nênia, que Firmino Rodrigues Silva publicou em 1837, considerada a primeira expressão do indianismo romântico.

Mais importante que questões de pioneirismo, a proximidade de Magalhães com Januário da Cunha Barbosa nos indica, também, que o interesse desses intelectuais na figura do indígena ultrapassava o universo exclusivamente literário. Percebe-se isso ao se analisar o escrito de Magalhães também à luz das iniciativas editoriais do cônego Januário, através das quais vem a público. Pois, ao mesmo tempo em que publicava o projeto literário indianista de seu amigo poeta, pelas páginas do mesmo Correio Oficial, no mesmo ano de 1834, o cônego Januário publicou uma série de seis artigos sobre "Civilização dos aborígenes do Brasil, ou catequese dos índios" nos quais esboçava os planos de uma política indigenista para o Império. Não cabe nos limites do presente artigo explorar os textos do cônego Januário, sendo mais interessante indicar as convergências entre seu projeto de intervenção político-social indigenista e 
investigação intelectual etno-histórica, que se desdobraria três anos depois na criação do Instituto Histórico e Geográfico Brasileiro (IHGB), com a proposta poética de Gonçalves de Magalhães. Ambos estavam centrados no indígena como elemento fundamental na busca de configuração simbólica do nacional e em dar sentido a seu futuro.

Essa convergência, que aqui captamos em seus primeiros momentos ainda um tanto desconexos, tenderia a se intensificar ao longo do século XIX, conformando o indianismo romântico, entendido, de forma ampla, como um esforço coletivo de reflexão sobre o nacional, com possibilidades de desdobramento em medidas político-sociais efetivas. $O$ indianismo romântico ultrapassava, assim, o movimento literário com o qual é tradicionalmente identificado, sem descartá-lo, tendo a escrita ficcional sobre o indígena dialogado com as políticas indigenistas e o indianismo etno-historiográfico (TREECE 2008).

Mas essa centralidade do indígena surgia no horizonte de interesses do cônego Januário, então redator do principal jornal governista e importante agente nos embates políticos da corte, a reboque da questão maior dos problemas gerados no âmbito da escravidão negra. Não se tratava, porém, de um movimento individual, restrito ao cônego. Naquele início da década de 1830, como reação à retomada do tráfico de escravos, a partir de 1833, houve uma intensa politização da escravidão, uma verdadeira "guinada antiescravista", nos termos de Tamis Parron, de setores da elite política (PARRON 2011, p. 84-103; EL YOUSEF 2010). Januário da Cunha Barbosa fazia parte de um grupo de políticos liberais moderados, liderados pelo deputado Evaristo da Veiga, que esboçou um discurso e medidas de caráter antiescravista, concentrando-se prioritariamente em defender o fim do tráfico de escravos. Não questionavam, porém, a propriedade escrava existente (da qual usufruíam), rechaçando medidas abolicionistas de caráter imediato. No entanto, buscavam elaborar um horizonte de expectativa alternativo, antiescravista, que previa a supressão da escravidão em um futuro para o qual, no entanto, não definiam um prazo preciso. Confrontaram-se, a partir de 1834, com os interesses dos produtores cafeeiros do vale do Paraíba, articulados pelo líder do Regresso conservador em ascensão, Bernardo Pereira de Vasconcelos, e seu empenho na legalização do tráfico e na extensão ilimitada da escravidão (PARRON 2010, p. 123-178).

Através dos escritos que difundiram em seus jornais, podemos compreender melhor os objetivos dessa "guinada antiescravista" de setores do liberalismo-moderado da corte nos anos 1830 e seus nexos com o indianismo nascente. Além do objetivo primeiro, já indicado, de luta pelo fim do tráfico mediante a defesa da aplicação da lei de 1831, outros dois objetivos se destacam da massa de escritos que produziram. Um segundo deles seria o investimento na criação de alternativas de mão de obra pretensamente livre, que viria substituir a escravidão negra, identificadas com a imigração europeia ou com o aldeamento de indígenas, constituindo-se esse o principal ponto de convergência com o indianismo em constituição (dentre outros, Correio Oficial, 03 abr. 1834). O terceiro ponto, avançado por Evaristo da Veiga, seria a necessidade de combater os preconceitos escravistas da elite senhorial, em um esforço de deslegitimação 
simbólica da escravidão que conquistasse a opinião pública (YOUSSEF 2010, p. 105-127). Esse último foi o ponto priorizado pelos nossos primeiros românticos, que se ligavam a todo esse movimento por meio dos intensos laços de sociabilidade que possuíam com o grupo de liberais moderados e com Evaristo da Veiga (PINASSI 1998, p. 60-66). Assim, a participação na "guinada antiescravista" também se fazia presente na própria produção intelectual dos intelectuais românticos. Se Torres Homem se destacou como o integrante do grupo romântico de mais claro empenho em desqualificar simbolicamente a escravidão, também Gonçalves de Magalhães não deixou de participar desse esforço. Ao longo dos anos 1830 e 1840, encontramos em sua obra poucos mas significativos trechos que deixam vislumbrar uma reflexão em andamento, alinhada ao antiescravismo liberal moderado.

Em seu livro Suspiros Poéticos e Saudades, de 1836, dois poemas de Magalhães exploravam a questão da escravidão. Em "A mocidade", a escravidão era apresentada como um mal herdado, algo da ordem do passado, implicando uma origem viciada que conspurcava e comprometia a mocidade brasileira, um mal não somente para os escravos mas principalmente para os senhores. Já a poesia "Invocação à Saudade" concentrava-se no sofrimento do escravo, em suas saudades. A escravidão era apresentada como contrária à lei divina e a insistência em descumprir o interdito sagrado resultava no castigo lançado sobre o Brasil, representado pela esterilidade do solo: "Que a lágrima do escravo esteriliza/ O terreno que orvalha" (MAGALHÃES 1836a, p. 302). Magalhães retomava o tema da reversão ao agente escravizador do mal imposto ao escravo e encerrava com um apelo esperançoso por um futuro sem escravidão: "Oh suspirada, oh cara Liberdade,/ Descende asinha do Africano à choça,/Seu pranto enxuga, quebra-lhe as cadeias" (MAGALHÃES 1836a, p. 302).

Também em seu conhecido "Discurso sobre a história da literatura do Brasil", de 1836, há um exercício de interpretação da história brasileira em que a crítica à herança negativa da colonização resvalava para a questão da escravidão, cuja continuidade futura representaria um empecilho ao progresso: "A Deus praza, que este perigoso fermento, que entre nós gira, $[\ldots]$ e sobre tudo a escravidão, tão contrária ao desenvolvimento da indústria, e das artes, e tão perniciosa à moral, não empeçam sua marcha, e seu engrandecimento" (MAGALHÃES 1836b, p. 141).

Às ameaças econômica e moral, acima indicadas, a experiência de contato direto com a violência das rebeliões regenciais iria adicionar à caracterização da escravidão pelo poeta uma terceira ameaça, mais imediata e incontornável: aquela à segurança e à vida de senhores e homens livres em geral. É o que depreendemos da memória de 1848, sobre a Balaiada, rebelião de cuja repressão Magalhães participara, entre 1840 e 41, como secretário do futuro Duque de Caxias. Na memória, o autor sondava as "causas morais" profundas que explicariam a quebra da ordem social no Maranhão conflagrado. E lá encontrava, em uma população de 217 mil almas, cerca de 80 mil escravos mal acomodados "ao jugo do senhorio", um fator de ameaça constante à classe senhorial, principalmente no caso do "negro Cosme, [...] [que] começava a ser, 
então, a figura que mais assustava os fazendeiros, por achar-se à frente de três mil escravos por ele sublevados" (MAGALHÃES 1858, p. 118).

Durante os conturbados anos 1830 e 1840, Magalhães tematizara a figura do escravo negro, apresentado sob o signo do medo, como uma ameaça aos senhores e à estabilidade social da nascente nação brasileira. Tratava-se de um momento em que se acirraram os debates políticos sobre o tráfico, colocando a sociedade brasileira diante do dilema de escolher entre expectativas conflitantes sobre o papel da escravidão na configuração da nação. Magalhães opôs-se aos que defendiam sua expansão futura ilimitada, orientando-se por um horizonte de expectativa antiescravista. A escrita de seu poema épico deu-se durante essa forte politização da escravidão, o que permite considerá-lo sob uma nova perspectiva. Ele pode, assim, ser visto como um exercício de reelaboração do espaço de experiência nacional por meio da linguagem, vista como superior, da poesia, um exercício de escrita que conferia um lugar de destaque para o tratamento do papel da escravidão nas origens da nação. Cabe analisar qual leitura do passado foi essa e como a escravidão nela tinha um papel central.

\section{A Confederação dos Tamoios: a escravidão como impedimento do sublime e causa da fábula}

Entrando propriamente na análise do texto de A Confederação dos Tamoios, percebe-se que Magalhães tende a seguir a tradição do gênero ao apresentar as partes constitutivas do épico. Na invocação, pede inspiração aos gênios do Brasil, em uma escolha que reforça a motivação nacionalista do poema. Seguem-se 122 versos de louvação à natureza brasileira, sua grandeza e esplendor (MAGALHÃES 2008, p. 860-863).

Mais do que inserção original da cor local, essa parte indica a aplicação de um discurso do sublime, entendido como uma estética visando a promover alguma forma de superação do estritamente humano, que poderia assumir desdobramentos de natureza ética e política (PEYRACHE-LEBORGNE 1997, p. 361-396). Aqui, essa tendência à transcendência visava não somente a atingir a subjetividade do leitor pelo estilo elevado, mas, como indica Marcos Nunes, expressava "as múltiplas ansiedades com relação às transformações históricas do período" (NUNES 2005, p. 73). Para um intelectual como Gonçalves de Magalhães, imbuído de uma autocompreensão do engajamento como uma missão sacerdotal de guia da nação, o sublime era mobilizado visando também a dar sentido e orientação à trajetória do conjunto da nacionalidade, o que representaria seu aspecto propriamente político. No caso específico, ao mobilizar a retórica do sublime no início do poema, Magalhães buscava frisar que essa grandeza e exuberância incomparáveis de sua natureza eram indicações claras de que o Brasil gozava de eleição divina e, por isso, teria um futuro grandioso a ser alcançado. O sublime da natureza implicava, aqui, a abertura para um futuro de redenção, entendido como um progresso e elevação à divindade, fins últimos da história nacional, conforme percebidos pelo saber poético.

Mas esse movimento, essa tendência à transcendência insuflada pela descrição da natureza, é bruscamente interrompido pela inserção do tema da 
colonização e, mais especificamente, pela introdução da escravidão e o rastro de sangue por ela gerado. A escravidão, ao aparecer pela primeira vez no poema, o faz como uma espécie de elemento que rompe o movimento ascendente do discurso sublime. Assim, o início propriamente da fábula é precedido por um lamento contra a escravidão:

Oh! E porque tão frio, tão amargo/ Pranto verteis, meus olhos magoados?/ Tanto dos índios vos contrista a sorte/ [...]/ Com que à escravidão os reduziram?/ A escravidão! Oh Céus! Quando no mundo/ Para sempre será tal crime extinto?/ Maus foram nossos pais para com eles./ Torpe ambição, nefária crueldade/ Os esforços mil vezes deslustraram/ dos primeiros colonos lusitanos,/ Que o amor ao áureo metal, e feios crimes/ A estas virgens plagas conduziram./ Não, dos canhões não foi o eco estrondoso/ Que ao índio impôs terror; nem mesmo a morte;/[...]/ Foi sim o cativeiro, algemas foram,/ Que alguns, ora colonos, de seus pulsos/ Aos pulsos dos indígenas passaram (MAGALHAES 2008, p. 864-866).

A passagem nos indica, primeiramente, o status temporal da escravidão, que é entendida como um mal que ainda se faz presente, um passado que não passa, mas cuja supressão futura é ansiada, ainda que incerta. Ela também mostra tanto a forma como a escravidão é concebida, quanto os princípios filosóficos que orientam a organização da fábula. A escravidão é vista como fruto não tanto da colonização em si, cujos esforços cristianizadores não deixam de ser elogiados, mas antes de uma disposição moral do colono, mais especificamente de sua "torpe ambição" e "nefária crueldade", guiadas pelo "amor do áureo metal", que impedem exatamente o caráter elevado, porque cristão, da colonização.

Ao opor a moral egoísta ao cristianismo abnegado, Magalhães aplicava à sua interpretação do conflito original da fábula a crítica filosófica que vinha desenvolvendo contra o que chamava de "moral do interesse", ou seja, a moral vista como responsável por um individualismo egoísta destrutivo da liberdade e da ordem, originária das filosofias sensualistas do século XVII e do iluminismo (Locke, Holbach, Condillac, etc.). Assim, Magalhães transpunha para o poema e acabava estruturando toda a fábula em torno de uma dualidade básica que contrapunha uma "moral do interesse", responsável por todos os males do mundo, e uma "moral da abnegação", calcada numa leitura liberalizante e não dogmática do cristianismo que viria a tudo redimir. Essa dualidade era originária da leitura de Magalhães da filosofia espiritualista de Victor Cousin, filosofia moral que informava o argumento de A Confederação dos Tamoios (MAGALHÃES 1836c).

Transposta para o poema, ela implicava uma leitura específica do passado brasileiro como sendo orientado por um conflito entre moralidades diversas cujos polos eram representados por dois agentes históricos: os colonos e os jesuítas (MAGALHÃES 2008, p. 867). Os colonos representavam o extremo negativo da moral egoísta, eram os agentes responsáveis diretos pelo mal original da escravidão. Sua mais acabada encarnação seria a figura do senhor de escravos Brás Cubas, tratado no canto sétimo, responsável direto pela escravização 
do herói Aimbirê e de seu pai, cuja morte pela exploração do cativeiro leva à rebelião do filho e consequente desenrolar de toda a trama.

Em contraposição, os jesuítas representavam o princípio redentor da história brasileira, pois encarnavam a moral religiosa a serviço da liberdade. No poema, eles lutavam com as armas da dissuasão contra a escravidão dos indígenas, ao mesmo tempo em que buscam aliviá-los das penas do cativeiro. Em outros termos, eram os responsáveis por uma alternativa de colonização coerente com o princípio da moral espiritualista que, caso vingasse, levaria a uma nação adequada à religião e à liberdade, valores que constituem o telos implícito da leitura de Magalhães sobre a história nacional.

Os indígenas, por sua vez, eram apresentados como confrontados com ambos os polos do processo colonizador. Representados como filhos de um ambiente primordial edênico, dotados de índole livre, hábitos sociais brandos e religiosidade natural, tendiam a se aproximar dos jesuítas e sua moral cristã, principalmente o herói Aimbirê. Mas a tensão inerente ao poema, e ao processo nele encenado, esteve na impossibilidade da realização de sua plena conversão ao cristianismo, em função de dois empecilhos extremos que o moderado Magalhães buscava condenar: a escravidão imposta pelos colonos portugueses (que impede a conversão de Jagoanharo após o sonho profético, no final do canto sexto) e a retórica de liberdade ilimitada dos calvinistas franceses (quando a conversão de Aimbirê é impedida pelo discurso de Ernesto no final do canto nono).

Vale considerar que o cativeiro esteve no centro do argumento, sendo mesmo sua causa. Afinal, a fábula consiste na busca do herói, o líder dos tamoios confederados Aimbirê, por vingar as violências que a escravidão trazida pelos ambiciosos colonos impusera a seu povo, cuja liberdade, vidas e segurança buscava defender. Assim, o que parece mover a trama do argumento não é a contraposição a um vago espírito "antilusitano". A contraposição básica, que percorre a quase totalidade da obra, não se dava entre indígenas $X$ portugueses, mas entre ambiciosos colonos escravistas $X$ índios em defesa de sua liberdade e jesuítas compassivos, ainda que uma das fragilidades do poema esteja em que essa contraposição não se manteve constante, tendendo a ser alterada nos dois últimos cantos do poema, quando os jesuítas unem-se definitivamente às autoridades coloniais.

Na raiz da contraposição estava a escravidão. As descrições de cenas de trabalho em que "uns faziam gemer a virgem terra/ com repetidos golpes de enxadas;/ outros nos densos matos mutilavam" (MAGALHÃES 2008, p. 867), assim como as referências a castigos físicos sobre "homens que outrora/ Livres à sombra sua se açoutavam" (MAGALHÃES 2008, p. 867) não deixavam muita dúvida de que não se estava somente fazendo referência a um sentido metafórico e amplo de escravidão, onipresente nas narrativas de origem nacional do século XIX, mas precisamente à instituição social da escravatura.

Assim, no sentido geral conferido ao processo de formação histórica da nação brasileira, o momento da origem seria marcado pela supressão da liberdade indígena e a introdução da instituição da escravidão, do que decorreria a dimensão violenta do processo colonizador. Essa seria paralela 
à sua dimensão redentora, que abria os caminhos para a evangelização e a consequente transcendência em direção à consumação do projeto salvífico da coletividade. Magalhães conferia, assim, um caráter ambíguo à sua leitura do processo da colonização, expresso pela metáfora que o descrevia como um "fruto pútrido", conforme a voz divina que aparece no sonho profético de Jagoanharo e o exorta à conversão: "Como de um fruto pútrido, lançado/ Sobre a terra, a semente germinando,/ Nova árvore produz, e novos frutos;/ Assim desses cruéis, corruptos homens, / Que vos flagelam hoje, um santo gérmen/ aqui produzirá filhos melhores" (MAGALHÃES 2008, p. 983). As forças negativas que suprimiam violentamente a sociedade indígena traziam o germe cristão de sua superação e elevação em uma fase superior, seguindo o modelo palingenético de transição cataclísmica de épocas, marcado pela morte seguida de ressureição das sociedades, que Magalhães recuperara do filósofo e poeta francês Ballanche (FERRETTI 2011). Nesse processo, a escravidão conferia uma marca indelével de violência que se apresentava como herança ao presente e comprometimento do futuro, conforme explorado no canto sétimo.

\section{Canto sétimo: à sombra do tronco do ipê, o inferno da escravidão}

Destaque deve ser dado ao canto sétimo, por corresponder a um episódio de fábula importante para a presente análise, na medida em que é dedicado, em sua quase totalidade, a abordar a questão da escravidão. Nele, o herói Aimbirê decide ir buscar os restos mal sepultados de seu pai, morto no cativeiro. A busca dos despojos paternos constitui importante metáfora do crime original não resolvido e fonte de todo conflito e de toda violência vigentes. Em última instância, esse episódio aclara toda a história de Aimbirê e sua rebelião, indicando o conflito profundo que dá origem ao conjunto da fábula. Cabe considerar que o diálogo do herói reconstitui, em mais uma cena patética, as condições da morte de seu pai e de sua consequente rebelião:

Ah! Tu não sabes o que é ser escravo; / Eu sei o que isso é!... Quando em tal penso/ Abrasa-me o furor... Meu pai, coitado! /Já velho e enfermo, sem poder seguir-me, na escuridão morreu; e se inda eu vivo/ É só para vingar tão grande infâmia. / Eles mo pagarão com um mar de sangue! (MAGALHÃES 2008, p. 996)

Mais uma vez, o cativeiro encontra-se na raiz de todo o mal e da violência. As lágrimas choradas pelo herói sob o tronco do velho ipê revelam a continuidade dos efeitos disruptivos da escravidão, apresentada, mais uma vez, como um passado que não passa. Revelam, ainda, um trabalho de luto não realizado e que, no limite, se prolongava até o presente do poeta. Sob o tronco do ipê permanecia aberta a chaga da escravidão, simbolizando a fonte de toda violência e a inconclusão do processo de formação nacional. ${ }^{3}$

\footnotetext{
${ }^{3}$ Não por acaso, 15 anos depois, em pleno debate sobre a Lei do Ventre Livre, o maior adversário da libertação dos filhos de escravas, José de Alencar, faria referência ao mesmo tronco do ipê (título de seu romance de 1871 ) invertendo o sentido dado por Magalhães. Alencar tentava mostrar que pela abnegação e lealdade do escravo se fechava a chaga da usurpação original e restituía-se a propriedade ao seu justo senhor. Há uma clara intertextualidade entre A Confederação dos Tamoios, de Magalhães, e O Tronco do Ipê, de Alencar, e os
} 
Nesse sétimo canto, o poeta buscou apresentar a violência em toda sua veemência, revestindo-a com tonalidades demoníacas. Em continuidade direta ao recolhimento dos restos paternos, Aimbirê decide vingar-se de seu ex-senhor, o ambicioso Brás Cubas, patriarca escravista e síntese de todos os vícios do colonizador. Ele é apresentado como "uma alma que do ardente inferno escapa", enquanto ao atacá-lo Aimbirê age "como um demônio aferra uma alma danada/ que por pacto infernal Ihe está sujeita" (MAGALHÃES 2008, p. 999). $O$ encontro entre $\mathrm{o}$ ambicioso escravocrata e $\mathrm{O}$ vingativo rebelde corresponde a uma cena demoníaca, um "pacto infernal" efetivamente, em que ambos aparecem equalizados por comum degradação. O conflito entre senhor e (ex-) escravo, tematizado no episódio, corresponde, no conjunto do poema, a uma descida aos infernos, ao inferno da escravidão, talvez o ponto mais baixo de toda a obra, em evidente contraste com os momentos de elevação acionados pela estética do sublime.

Mas a importância desse canto sétimo está no desenvolvimento que o poeta dá ao tratamento da escravidão. Magalhães apresenta a ação do herói de forma a passar pelos principais problemas gerados pela instituição. Apresenta, assim, de forma subliminar, um elenco dos males causados pelo cativeiro, que passo a tratar em subtópicos.

\section{A escravidão desumaniza o escravo}

Esse argumento encontra-se implícito ao discurso proferido por Aimbirê a seu companheiro Parabuçu, quando juntos rumavam em busca dos ossos do pai do herói e telepaticamente têm, ao mesmo tempo, uma visão do cativeiro de Iguaçu, amada do herói, que leva a uma divagação sobre a escravidão:

Não, tu não sabes o que é ser escravo!/ Não ser senhor de si, viver sem honra, / Acordar e dormir sem ter vontade, / Calado obedecer com rosto alegre, / Sofrer sem murmurar, comer chorando,/ Não ter filhos, nem pais, não ter amigos,/ Trabalhar, trabalhar ao sol e à chuva, / e isto a fim que um senhor tranquilo viva,/ No meio da fartura à custa alheia!.../ Ah! tu não sabes o que é ser escravo;/ Eu sei o que isso é!... Quando em tal penso/ Abrasa-me o furor [...] (MAGALHÃES 2008, VII, 126-136, p. 995-996).

Proferido pelo índio em revolta, o lamento está vazado em uma estratégia retórica que apresenta o escravo como ser sensível, vítima da violência da escravidão que o priva dos principais atributos do homem, conforme a concepção oitocentista: não somente a óbvia e fundamental liberdade, mas a espontaneidade afetiva, a família, a honra, o tempo.

Também a descrição, por Aimbirê, do martírio imposto por Brás Cubas a seu amigo Guaratiba motiva uma verdadeira cena de sadismo e crueldade senhorial, raramente encontrada na produção literária brasileira do século XIX, mesmo a antiescravista, mais atenta aos males que o escravo perpetra ao senhor: 
Lembras-te tu do pobre Guaratiba?/ Tu o amarraste a um tronco, em cuja cepa/ Havia um formigueiro, e o flagelaste/ Até fazer saltar co'o sangue a pele/ Das costas, que uma chaga Ihe ficaram;/ As formigas, em chusmas negrejando/ Sobre o convulso corpo, o remordiam,/ E tu sem coração, feroz zombavas! (MAGALHÃES 2008, p. 1001)

Tronco, flagelação, sadismo senhorial: seguramente Magalhães não apresentava somente uma alusão genérica a uma escravidão abstrata. Nesses trechos aparece claramente o caráter moral do épico, que busca instruir deleitando, ainda que não se trate de deleite, e sim de incentivar o seu exato contrário, o pathos, movendo retoricamente as emoções do leitor com um fim de utilidade, fazendo-o se compadecer da sorte do cativo, recurso não raro de algumas poesias antiescravistas, mormente de origem inglesa e norte-americana, em países onde a retórica do sentimentalismo foi a base da literatura abolicionista (CAREY 2005).

\section{A escravidão destrói a terra e compromete a produção}

O argumento, já trabalhado na poesia "A Saudade", conforme visto, surge no canto sétimo da descrição que o poeta faz da área onde se encontrava a fazenda escravista de Brás Cubas, próxima ao ipê. O terreno, fruto da exploração por mãos escravas, é descrito como "...um vale, onde por terra se estendiam/ Ingentes troncos de árvores anosas, / Que os machados a custo destruíram, / E o fogo, a cinza reduzira os ramos, / Campo abrindo ao mesquinho pasto do homem, / que assim desseca imprevidente a terra" (MAGALHÃES 2008, p. 996). A destruição das matas seculares, lócus por excelência da liberdade indígena, dá lugar ao campo queimado, ao pasto estéril, fechado ao futuro e à abundância. Magalhães esboçava uma crítica ecológica ao cativeiro, visando reverter o argumento senhorial que o relacionava à abundância econômica e, no caso do político pró-escravista Bernardo Pereira de Vasconcelos, à própria civilização do país. O poeta seguia outra narrativa, relacionando paisagem escravista com esterilidade, mostrando-a como "ruínas" de um "bosque secular", em que o martírio da natureza era lamentado pelo rio próximo "que parece/ Carpir tamanho estrago" (MAGALHÃES 2008, p. 996-997).

\section{A escravidão é uma ameaça à segurança do próprio senhor}

De todos os argumentos, este é, seguramente, o mais investido pelo autor que, conforme já indicado, está presente no canto I, mas que é aprofundado no canto sétimo, correspondendo ao episódio infernal tratado acima. Nele, Aimbirê arrasta violentamente o escravocrata Brás Cubas até o tronco do ipê onde jazia seu pai e decide matá-lo. A estratégia narrativa escolhida pelo poeta é significativa de sua intencionalidade. Ao invés de ressaltar a crueldade do ex-escravo, ele Ihe concede a palavra. Em um longo discurso, o herói relata toda a trajetória de sua vida a partir da chegada de Brás Cubas. Pela fala de Aimbirê, Magalhães realiza um verdadeiro julgamento do senhor de escravos, revelando o rol de suas culpas. Assim, aos nossos olhos se desenrola a morte da mulher grávida de Aimbirê, o tiro que sua mãe recebeu, a escravização conjunta de seu pai e de sua pequena filha, que o obriga a se entregar ao cativeiro para 
protegê-los, o já descrito martírio de seu amigo Guaratiba. O poeta buscava evidenciar a violência intrínseca à escravatura e o fazia no exato momento em que o escravo pretendia matar o senhor, o que poderia servir como uma justificativa da violência do subalterno. Mas esse caráter legitimador não precisa ser mobilizado, uma vez que, por intercessão da filha de Brás Cubas, o herói Aimbirê poupa a vida do senhor escravista, responsável pela desgraça de sua família e de seus compatriotas, misericórdia que somente elevava moralmente o herói e indicava sua predisposição natural à conversão cristã.

\section{A escravidão é contrária à moral}

O argumento é abordado quando se trata da prisão da bela e casta Iguaçu, amada do herói que havia sido capturada junto com outras índias e levada para Piratininga, o quartel general dos colonos, pelo pérfido Francisco Dias. Este é apresentado como "brutal" e "impudico" que, atraído pela beleza de Iguaçu, "para escrava impura [lhe] queria". O senhor aparecia, assim, relacionado à violência sexual e à luxúria, elemento complementar da "moral do interesse" que constituía o polo negativo da dualidade cousiniana que baseava o relato, conforme vimos. A ela se contrapunha a castidade virginal e virtuosa da indígena Iguaçu, que se dedicava "... a viver, lutar, nobre esquivando/ Do seu torpe raptor a impudicícia" movida pela "força sobre-humana,/ que ao feminil recato o céu inspira" (MAGALHÃES 2008, p. 1005). A argumentação é interessante e original no conjunto dos discursos antiescravistas dos românticos brasileiros anteriores a Castro Alves, na medida em que o agente da imoralidade não é a escrava, mas o próprio escravocrata.

\section{A escravidão é contrária a Deus e à Civilização}

O poeta desenvolve o argumento ao tratar da iniciativa de Anchieta em buscar convencer o escravista e imoral Francisco Dias a libertar Iguaçu. O jesuíta buscava também convencer Dias a um ato que poderia servir de modelo a outros colonos, que então libertariam seus escravos e deixariam de escravizar indígenas no futuro. Em suma, uma defesa da manumissão. O poeta indicava, por meio da iniciativa dos jesuítas, os efeitos precisos da "moral da abnegação" na vida dos primórdios da colônia, indicando sua incompatibilidade com a escravidão instituída e seus esforços em criar uma lógica alternativa, livre e cristã. Mostrava também a resistência dos colonos aos rompantes antiescravistas dos jesuítas, colocando na boca de Francisco Dias um dos poucos e breves discursos que legitimavam a escravidão, discurso em relação ao qual o narrador deixa claro seu distanciamento, qualificando-o de "ímpia resposta". A ela Anchieta, em mais um lamento, revelava a oposição divina à escravidão:

Iguais os homens são; e cristãos devem/ Abraçar seus irmãos, do erro salvá-los,/ Guiá-los ao Senhor, morrer por eles,/ E não matá-los, como fazem lobos/ [...]/ Vós aos índios chamais brutos sem almas,/ E assim credes poder escravizá-los:/ Mas o que destes brutos vos distingue?/[...]/ E vós que os reduzis a escravos vossos,/ Para longe os mandais em troco de ouro!/ E por cem que vos caem nas duras garras,/ Mortos ficam centenas 
entre as chamas/ [...] Oh duros corações! Esta é a indústria,/ Este o nefando trato que vos ceva!/ E ousais chamá-los bárbaros selvagens?... (MAGALHÃES 2008, p. 1008-1009).

Ao afirmar a liberdade e a igualdade originais fruto da vontade divina, o poeta apresentava a escravidão como uma afronta aos planos divinos. Também acusava o "nefando trato", o tráfico de escravos índios, como prática bárbara, o contrário mesmo da civilização.

Por fim, vale considerar que, nos dois últimos cantos, fracassa a última tentativa dos jesuítas de apaziguar os tamoios rebelados, seduzidos que foram pelo discurso de igualdade e liberdade ilimitadas proferido pelos calvinistas franceses. A partir daí, há uma redefinição dos personagens e do posicionamento do poeta em relação a eles. Termina-se louvando a união de jesuítas com os colonos para a fundação da cidade do Rio de Janeiro, célula original da nova nação, criada sobre o sacrifício do herói e seu povo.

\section{Considerações finais}

Indício do diálogo entre a literatura e a historiografia no oitocentos brasileiro foi o fato de o historiador Varnhagen tecer críticas ao poema de Magalhães. A reação do poeta veio em nota à segunda edição de seu poema: "Se a redenção do gênero humano liga-se ao pecado de Adão, a fundação do Rio de Janeiro, hoje capital do grande império, liga-se neste poema à defesa heroica dos tamoios dirigidos por Aimbirê..." (MAGALHÃES 2008, p. 1092). A leitura 188 da história de Magalhães era informada, a seu modo, pelo modelo bíblico da queda e redenção, tão comum no romantismo fascinado pela epopeia espiritual de John Milton (ABRAMS 1992). E o episódio narrado em $A$ Confederação dos Tamoios representaria exatamente a violência cataclísmica, típica do modelo palingenético de transições caro a Magalhães, que está na origem da trajetória da nação. A morte do índio revoltado pelos efeitos da escravidão representa o pecado original da nação brasileira. A escravidão estaria, assim, na raiz da queda que dá sentido a toda a trajetória nacional. Ele exigia uma redenção, que estaria indissociavelmente ligada à expansão dos valores cristãos introduzidos pelos jesuítas, ambiguamente, no próprio processo de colonização.

Essa redenção, no entanto, somente seria desenvolvida no estudo erudito que Magalhães publicou na revista do IHGB em 1860, como continuidade à discussão com Varnhagen. Ela corresponderia à busca pela "reabilitação do indígena", que seria dada pela implantação de uma política indigenista de catequese que permitisse a substituição do trabalho do escravo negro pelo do indígena aldeado, na esteira das propostas indigenistas que o cônego Januário propusera desde 1834 e implantara no IHGB, quando Magalhães dava os primeiros passos na redação de seu épico. "É uma dívida sagrada, contraída pelos nossos maiores, e por nós, que em pleno gozo estamos das terras tomadas aos pais desses infelizes" (MAGALHÃES 1860, p. 236).

O indianismo de Magalhães era, conforme vimos, um indigenismo, e era também um antiescravismo, uma via para suprimir a escravidão sem 
abolicionismo, sem tocar na propriedade escrava, mas diluindo-a a longo prazo mediante sua substituição pelo indígena "reabilitado" como mão de obra supostamente livre. Só assim, com a substituição lenta e gradual da escravidão negra pelo trabalho indígena, se fecharia definitivamente a chaga aberta aos pés do tronco do ipê, permitindo alcançar, no futuro, a harmonia social e a realização dos sublimes planos dos nossos primeiros românticos, planos de criar uma nação plenamente livre e cristã nos trópicos.

\section{Referências bibliográficas}

ABRAMS, M. H. El romanticismo: tradición y revolución. Tradução de Tomás Segovia. Madri: Visor, 1992.

O Espelho e a lâmpada: teoria romântica e tradição crítica. São Paulo: ed. Unesp, 2010.

ARAUJO, Valdei Lopes. A experiência do tempo: conceitos e narrativas na formação nacional brasileira (1813-1845). São Paulo: Hucitec, 2008.

BRIX, Michel. Platon et platonisme dans la litterature française de l'age romantique. Romantisme, n. 113, 2001.

CAMPATO Jr., João Adalberto. A Confederação de Magalhães: epopeia e necessidade cultural. In: TEIXEIRA, Ivan (org.). Épicos: Prosopopeia: O Uraguai: Caramuru: Vila Rica: A Confederação dos Tamoios: I-JucaPirama. São Paulo: Edusp; Imprensa Oficial do Estado de SP, 2008.

CAREY, Brycchan. British Abolitionism and the Rhetoric of Sensibility: writing, sentiment and slavery, 1760-1807. Basingstoke: Palgrave Macmillan, 2005.

CHAUVIN, Cédric. Théorie de l'épopée et philosophie de l'histoire: le «mythe de la mort de l'épopée». In : NEIVA, Saulo (Direction). Déclin et confin de I' Épopée au XIX' siécle. Tübingen: Gunter Narr Verlag, 2008.

EL YOUSEFF, Alain. Imprensa e escravidão: política e tráfico negreiro no Império do Brasil. Rio de Janeiro, 1822-1850. Dissertação (Mestrado em História Social), Universidade de São Paulo, São Paulo, 2010.

FERRETTI, Danilo J Zioni. Gonçalves de Magalhães e o sacerdócio moral do poeta romântico em tempos de guerra civil. Almanack, n. 2, 2011.

GOYET, Florence. L'Épopée. Vox poetica, 2009. Disponível em: www.voxpoetica.com/sflgc/biblio/goyet.html. Acesso em 20 mar. 2014.

GUIMARÃES, Manoel Salgado. Nação e Civilização nos trópicos; o Instituto Histórico e Geográfico Brasileiro e o projeto de uma história nacional.

Estudos Históricos, n. 1, 1988.

HANSEN, João Adolfo. Introdução: Notas sobre o gênero épico. In: TEIXEIRA, Ivan (org.) Épicos: Prosopopeia: O Uraguai: Caramuru: Vila Rica: A Confederação dos Tamoios: I-Juca-Pirama. São Paulo: Edusp; Imprensa Oficial do Estado de SP, 2008. 
HARTOG, François. Ce que la littérature fait de I'histoire et à I'histoire. Fabula / Les colloques, Littérature et histoire en débats, 2013. Disponível em: http://www.fabula.org/colloques/document2088.php. Acesso em 21 mar. 2014.

JOUHAUD, Christian; RIBARD, Dinah; SCHAPIRA, Nicolas. Histoire, Litterature, Temoignage: écrire les malheurs du temps. Paris: Gallimard, 2009.

KOSELLECK. historia/Historia. Tradução e introdução de Antonio Gomez Ramos. Madrid: Trotta, 2004.

LYON-CAEN, Judith; RIBARD, Dinah. L'historien et le littéraire. Paris: la Découverte, 2010.

MAGALHÃES, D. J. G. Suspiros poéticos e saudades. Paris: Dauvin et Fontaine, 1836a. Disponível em: http://www.brasiliana.usp.br/bbd/ handle/1918/01088800\#page/1/mode/1up. Acesso em 5 maio 2014.

. Discurso sobre a história da literatura do Brasil. Nitheroy. Vol 1. Paris: Dauvin et Fontaine, 1836b. Disponível em: http://www.brasiliana. usp.br/bbd/handle/1918/63. Acesso em 5 maio 2014.

. Filosofia da religião, sua relação com a moral, e sua missão social. Nitheroy. Vol. 2. Paris: Dauvin et Fontaine, 1836c. Disponível em: http:// www.brasiliana.usp.br/bbd/handle/1918/63. Acesso em 5 maio 2014.

190 - Carta a Araújo Porto Alegre sobre a crítica à Confederação dos Tamoios: cópia. Biblioteca Nacional, Sessão de Manuscritos 26, 4, 81, 1856.

MAGALHÃES, D. J. G. A alma e o cérebro: estudos de psicologia e fisiologia. Rio de Janeiro: Livraria Garnier, 1876. Disponível em: http://www.brasiliana. usp.br/bbd/handle/1918/01086900. Acesso em: 5 maio 2014.

MAgAlhães, D. J. G. A Revolução da Província do Maranhão, 18391840. São Luiz, Typografia do Progresso,1858. Disponível em: http:// www.brasiliana.usp.br/bbd/handle/1918/01088700\#page/1/mode/1up. Acesso em: 5 maio 2014.

MAGALHÃES, D. G. de. A Confederação dos Tamoios. In: TEIXEIRA, Ivan (org.). Épicos: Prosopopeia: O Uraguai: Caramuru: Vila Rica: A Confederação dos Tamoios: I-Juca-Pirama. São Paulo: Edusp; Imprensa Oficial do Estado de SP, 2008.

MILLET, Claude. Les larmes de l'épopée. Des Martyrs à La Legende des siécles. In : NEIVA, Saulo (Direction). Déclin et confin de I'Épopée au XIXe siécle. Tübingen: Gunter Narr Verlag, 2008.

NEIVA, Saulo (Direction). Déclin et confin de I'Épopée au XIXe siécle. Tübingen: Gunter Narr Verlag, 2008.

NEIVA, Saulo. Epopée et modernité: sur la caducité et la réhabilitation d'un genre. www. revue-analyses.org, v. 9, n. 3, 2014. Disponível em: 
https://uottawa.scholarsportal.info/ojs/index.php/revue-analyses/ article/viewFile/1188/1046. Acesso em: 5 nov. 2014.

NUNES, Marcos Machado. O Sublime tropical: transcendência, natureza e nação na formação do romantismo brasileiro. Tese (Doutorado em Literatura Comparada), Programa de Pós-Graduação em Letras, Universidade Federal do Rio Grande do Sul, Porto Alegre, 2005.

PARRON, Tamis. A Política da escravidão no Império do Brasil, 18261865. Rio de Janeiro: Civilização Brasileira, 2011.

PEYRACHE-LEBORGNE. La poétique du sublime: de la fin des lumiéres au romantisme. Paris: Honoré Champion, 1997.

PINASSI, Maria Orlanda. Três devotos, uma fé, nenhum milagre. São Paulo: ed. Unesp, 1998.

RAMALHO, Christina. Vozes épicas: história e mito segundo as mulheres. Tese (Doutorado em Letras) Universidade Federal do Rio de Janeiro, Rio de Janeiro, 2004.

ROZEAUX, Sébastien. La genèse d'un «grand monument national»: littérature et milieu littéraire au Brésil à l'époque imperiale (1822-c1880). Tese (Doutorado em História Contemporânea) Université Lille Nord de France, Lille, 2012.

SILVEIRA, Pedro Telles da. Fiç̧ão, literatura e história através da 'Crônica do descobrimento do Brasil (1840)' de Francisco Adolfo de Varnhagen. História da Historiografia, Ouro Preto, n. 3, 2009.

TREECE, David. Exilados, Aliados e Rebeldes: o movimento indianista, a política indigenista e o Estado-nação imperial. São Paulo: Nankin, Edusp, 2008. 